\title{
Study of effect of sodium arsenite on lipid metabolism of Heteropneustes fossilis and the chelating effect of zeolite
}

\author{
Jayasree Balasubramanian ${ }^{1}$, Anil Kumar ${ }^{2, *}$ \\ ${ }^{1}$ Department of Zoology, St. Thomas College, Bhilai, CG, India \\ ${ }^{2}$ Department of Zoology, Govt. V. Y. T. PG. Autonomous College, Durg, CG, India
}

\section{Email address:}

jaysreebalu@gmail.com(J. Balasubramanian), aimum_aishley@yahoo.co.in(A. Kumar)

\section{To cite this article:}

Jayasree Balasubramanian, Anil Kumar. Study of Effect of Sodium Arsenite on Lipid Metabolism of Heteropneustes Fossilis and the Chelating Effect of Zeolite. International Journal of Advances in Biosciences and Bioengineering. Vol. 1, No. 1, 2013, pp. $22-27$. doi: 10.11648/j.abb.20130101.13

\begin{abstract}
Arsenic, the metal pollutant found naturally in groundwater and unnaturally in mine waste sites and agricultural runoff, has been considered toxic to humans for several millennia. Fishes, which are rich sources of a healthy diet, are endangered by hazardous contaminants in water, like arsenic, which are transferred through food chain. In the present work the effect of different concentrations of sodium arsenite on lipid metabolism in Heteropneustes fossilis, and the chelating effect of synthetic zeolite was studied from liver. Fishes were exposed to two different concentrations of sodium arsenite ( $200 \mathrm{ml}$ and $400 \mathrm{ml}$ of $1 \%$ solution), for 3 different durations (3days, 7 days and 15 days). The concentrations of total Cholesterol, HDL, LDL and triglyceride was found significantly increased $(\mathrm{P}<0.05)$ along with increasing concentration and duration of sodium arsenite. The toxic effect was found recovered after application of synthetic zeolite for all parameters. The results suggest that, zeolite is a potential compound for decreasing significantly the load of toxicity of arsenic in aquatic fauna.
\end{abstract}

Keywords: Sodium Arsenite, Synthetic Zeolite, Heteropneustes Fossilis, Lipid Metabolism, Adsorption

\section{Introduction}

Arsenic toxicity is a global health problem affecting many millions of people. Since last decade, the wide spread nature of human exposure to arsenic in drinking water has become very apparent in many countries. In India besides west Bengal, lakhs of people are suffering from higher concentration of arsenic (above WHO permissible limits) from Tripura and Chhattisgarh state. In these areas the source of arsenic is geological in origin, contaminating aquifers which provide water for over one million tube wells[1].

Levels of arsenic in fish and seafood may be high, because fish absorb arsenic from the water they live in. Luckily this is mainly the fairly harmless organic form of arsenic, but fish that contain significant amounts of inorganic arsenic may be a danger to human health, since fishes form a major component of their $\operatorname{diet}[2]$.

Arsenic is found widely in nature, most often combined with oxygen, chlorine and sulphur. It is found in tracequantities in all living things, in the atmosphere, water and geological formations. It is usually found also in ores containing gold, silver, cobalt, nickel and antimony[3, 4]. There are more than 150 known arsenic bearing minerals.

The most significant source of commercial arsenic is a byproduct from treatment of copper, lead, cobalt and gold ores. Inorganic arsenic occurs mainly in different kinds of rocks. It is most commonly found with sulphide ores as arseno pyrites. Arsenic combined with carbon and hydrogen is classified as organic arsenic[2].

Zeolites are microporous, aluminosilicate minerals commonly used as commercial adsorbents. They were introduced in 1954 as adsorbents for industrial separations and purifications. Because of their unique porous properties, zeolites are now used in a variety of applications with world production estimated to be in the range of 2.5 million to 3million metric tons in year 2008[5]. Zeolites are widely used in industry for water purification, as catalysts, and in nuclear reprocessing. One of the earliest applications of a natural zeolite was in removal and purification of cesium and strontium radioisotopes[6].

They are well known for their ion exchange capacity. 
The role of zeolites in the conversion of solid and liquid hazardous wastes into environmentally acceptable products has also been demonstrated. Several zeolites, namely clinoptilolite, chabazaite, SZP1, 13X and 5A have been identified as potential candidates for arsenic removal from water. Synthetic zeolites are useful because of their controlled and known physico-chemical properties relative to that for natural zeolites. It has been observed that the $\mathrm{H}+$ and $\mathrm{NH} 4+$ forms of the synthetic zeolites were capable of removing arsenate to $50 \mathrm{ppb}$ within 15 minutes, which is the current permitted maximum contaminant level (MCL) for arsenic in the United States[7].

It is considered as effective adsorbent because it can adsorb heavy metals from the wastewater sample. The fact that zeolite exchangeable ions are relatively innocuous (sodium, calcium, and potassium ions) makes them particularly suitable for removing undesirable heavy metal ions from industrial effluent waters[8,9].

In the present study the efficiency of synthetic zeolite, type $\mathrm{Y}$, in removing arsenic toxicity was carried out.

\section{Materials and Methods}

The Teleost cat fish, Heteropneustes fossilis, was selected for experiment and were collected from a local pond. The fish selected for experiment was 7-8 inch of length and average weight of 125-150 gms. and were maintained in glass aquarium of $2 \frac{1}{2}$ feet $x 1 \frac{1}{2}$ feet $\times 1$ $1 / 2$ feet dimension, with $20 \mathrm{~L}$ of chlorine-free bore well water. The fishes selected for experiment were first acclimatized in the lab. A total of 25 fishes were taken and divided into five experimental groups, each with 5 fishes. The first group of fishes was selected for control set and next four for experimental sets, $200 \mathrm{ml}$ sodium arsenite in $20 \mathrm{~L}$ water, $400 \mathrm{ml}$ sodium arsenite in $20 \mathrm{~L}$ water, $200 \mathrm{ml}$ sodium arsenite in $20 \mathrm{~L}$ water with zeolite and $400 \mathrm{ml}$ sodium arsenite in $20 \mathrm{~L}$ water with zeolite.

The test chemical selected for the experiment was arsenic trioxide obtained from s.d. Fine - Chem Ltd, Mumbai. The experimental dose of $200 \mathrm{ml}$ of $1 \%$ sodium arsenite was prepared for $20 \mathrm{~L}$ water by dissolving $100 \mathrm{mg}$ of arsenic trioxide per $100 \mathrm{ml}$ of aqueous solution of sodium hydroxide, to make the stock solution. A similar dose of $400 \mathrm{ml}(1 \%)$ for $20 \mathrm{~L}$ of water was also prepared. Another test chemical selected as chelating agent was Zeolite (Type-Y, Sodium form), obtained from Hi-Media Laboratories Ltd., Mumbai. A combination of Zeolite (1\%) with $200 \mathrm{ml}$ and $400 \mathrm{ml}$ of sodium arsenite solution was prepared for the experiment. For all sets of experiments, three durations of exposures were selected, i.e., 3days, 7days and 15days for evaluation of acute toxicity.

After exposure for specific dose and duration, liver tissue was taken out and was kept in ice cubes and then homogenized in a homogenizer with 5\% trypsin. The homogenate was filtered before the biochemical analyses were done. Estimation of total cholesterol was done by enzymatic method and HDL and LDL by colorimetric method and Triglyceride by monostep enzymatic method. Statistical analysis of the results was done by two way ANOVA.

\section{Results}

\subsection{Alteration in Total Cholesterol}

In our observation (Table-1) the average control value for total cholesterol from liver was found to be $16.83 \pm 1.19 \mathrm{mg} / \mathrm{dl}$. After exposure to $200 \mathrm{ml}$ of sodium arsenite for three days, it was found decreased up to $7.86 \pm 2.09 \mathrm{mg} / \mathrm{dl}$, for 7 days exposure it was $15.3 \pm 6.95 \mathrm{mg} / \mathrm{dl}$, and for 15 days exposure of the same dose, the concentration of cholesterol obtained was $44.34 \pm 4.92 \mathrm{mg} / \mathrm{dl}$. When exposed to $400 \mathrm{ml}$ of the test solution for three days, the average amount of total cholesterol was increased to $46.14 \pm 2.27 \mathrm{mg} / \mathrm{dl}$, for 7 days exposure the average concentration was $40.16 \pm 5.72 \mathrm{mg} / \mathrm{dl}$ and for 15 days exposure the value was $48.33 \pm 7.01 \mathrm{mg} / \mathrm{dl}$. But when exposed to $200 \mathrm{ml}$ solution of zeolite along with sodium arsenite the average concentration obtained was decreased to $24.10 \pm 1.53 \mathrm{mg} / \mathrm{dl}$ for 3days, $20.75 \pm 4.99 \mathrm{mg} / \mathrm{dl}$ for 7 days and $29.75 \pm 11.11 \mathrm{mg} / \mathrm{dl}$ for 15 days exposure. Similarly when exposed to $400 \mathrm{ml}$ of sodium arsenite with zeolite, average concentration measured was $11.73 \pm 4.93 \mathrm{mg} / \mathrm{dl}$ for 3days exposure; $15.82 \pm 1.06 \mathrm{mg} / \mathrm{dl}$ for 7 days exposure; $12.22 \pm 0.86 \mathrm{mg} / \mathrm{dl}$ for 15 days exposure. (Fig. 1)

All alterations in total cholesterol from liver extract of Heteropneustes fossilis for dose based treatments and treatment with zeolite was found statistically significant (Table: 2) except for $200 \mathrm{ml}$ sodium arsenite with $200 \mathrm{ml}$ sodium arsenite \& zeolite $(\mathrm{F}=2.37>5 \% \mathrm{P})$. But alterations among duration of treatments were found non-significant (Table: 2$)$, except control to 15 days $(\mathrm{F}=13.5<5 \% \mathrm{P})$. The initial decrease in cholesterol might be due to initial metabolic activation caused by intoxication and final increase might be due to interaction of sodium arsenite with enzymatic pool for cholesterol metabolism. After treatment with zeolite the cholesterol concentration was found decreased significantly to normal range, in comparison to treated ones (Table:2). Above experiment revealed that low dose of zeolite is not very effective for chelation and maximum duration of exposure to sodium arsenite is more toxic.

\subsection{Alterations in HDL Cholesterol}

The average control value for HDL cholesterol from liver was found to be $1.48 \pm 1.05 \mathrm{mg} / \mathrm{dl}$. After exposure to $200 \mathrm{ml}$ of sodium arsenite for three days, it was found decreased up to $0.97 \pm 0.35 \mathrm{mg} / \mathrm{dl}$, for 7 days exposure it was found increased to $4.55 \pm 1.23 \mathrm{mg} / \mathrm{dl}$, and for 15 days exposure of the same dose, the concentration of HDL cholesterol obtained was $3.80 \pm 0.56 \mathrm{mg} / \mathrm{dl}$. At the same 
time, when exposed to $400 \mathrm{ml}$ of the test solution for three days, the average amount of HDL cholesterol was increased to $3.36 \pm 2.24 \mathrm{mg} / \mathrm{dl}$; for 7 days exposure the average concentration was $6.25 \pm 0.86 \mathrm{mg} / \mathrm{dl}$ and for 15 days exposure the value was $11.56 \pm 0.61 \mathrm{mg} / \mathrm{dl}$. But when exposed to $200 \mathrm{ml}$ solution of zeolite along with sodium arsenite the average concentration obtained was $6.7 \pm 0.62 \mathrm{mg} / \mathrm{dl}$ for 3 days, $2.20 \pm 0.45 \mathrm{mg} / \mathrm{dl}$ for 7 days and $1.00 \pm 0.17 \mathrm{mg} / \mathrm{dl}$ for 15 days exposure. Similarly when exposed to $400 \mathrm{ml}$ of sodium arsenite with zeolite, average concentration measured was $1.70 \pm 0.16 \mathrm{mg} / \mathrm{dl}$ for 3 days exposure; $1.2 \pm 0.05 \mathrm{mg} / \mathrm{dl}$ for 7days exposure; $1.38 \pm 0.20 \mathrm{mg} / \mathrm{dl}$ for 15 days exposure (Fig.2).

The alteration in HDL cholesterol from liver extract of Heteropneustes fossilis for dose based treatments, i.e, control to sodium arsenite $(400 \mathrm{ml})[\mathrm{F}=14.9<5 \% \mathrm{P}]$, sodium arsenite $(200 \mathrm{ml})$ to sodium arsenite $(400 \mathrm{ml})[\mathrm{F}=13.3<5 \% \mathrm{P}]$, sodium arsenite $(400 \mathrm{ml})$ to sodium arsenite + zeolite $(200 \mathrm{ml})[\mathrm{F}=13.1<5 \% \mathrm{P}]$ and sodium arsenite $(400 \mathrm{ml})$ to sodium arsenite + zeolite (400ml) $[\mathrm{F}=14.2<5 \% \mathrm{P}]$ were found significant (Table:2). But alterations among duration of treatments were found non-significant. The increase in HDL concentration was prominent for higher concentration of sodium arsenite (400ml). But the value decreased to normal range, in comparison to treated ones, after treatment with zeolite (Table: 2).

\subsection{Alterations in LDL Cholesterol}

The average control value for LDL cholesterol from liver was found to be $0.20 \pm 0.03 \mathrm{mg} / \mathrm{dl}$. After exposure to $200 \mathrm{ml}$ of sodium arsenite for three days, it was found increased up to $1.81 \pm 0.36 \mathrm{mg} / \mathrm{dl}$, for 7 days exposure it was found increased to $3.89 \pm 0.18 \mathrm{mg} / \mathrm{dl}$, and for 15 days exposure of the same dose, the concentration of LDL cholesterol obtained was $4.12 \pm 4.44 \mathrm{mg} / \mathrm{dl}$. At the same time, when exposed to $400 \mathrm{ml}$ of the test solution for three days, the average amount of LDL cholesterol was increased to $3.11 \pm 1.08 \mathrm{mg} / \mathrm{dl}$; for 7 days exposure the average concentration was $6.25 \pm 0.52 \mathrm{mg} / \mathrm{dl}$ and for 15 days exposure the value was $11.56 \pm 1.01 \mathrm{mg} / \mathrm{dl}$. But when exposed to $200 \mathrm{ml}$ solution of zeolite along with sodium arsenite the average concentration obtained was $2.10 \pm 0.21 \mathrm{mg} / \mathrm{dl}$ for 3 days, $2.20 \pm 0.70 \mathrm{mg} / \mathrm{dl}$ for 7 days and $1.00 \pm 0.06 \mathrm{mg} / \mathrm{dl}$ for 15 days exposure. Similarly when exposed to $400 \mathrm{ml}$ of sodium arsenite with zeolite, average concentration measured was $0.80 \pm 0.10 \mathrm{mg} / \mathrm{dl}$ for 3 days exposure; $\quad 0.70 \pm 0.08 \mathrm{mg} / \mathrm{dl}$ for 7 days exposure; $0.30 \pm 0.03 \mathrm{mg} / \mathrm{dl}$ for 15 days exposure. The results indicate that the values have come to normal after treatment with

zeolite, due to chelation (Fig.3).

The alteration in LDL cholesterol from liver extract of Heteropneustes fossilis for dose based treatments with sodium arsenite and sodium, arsenite + zeolite was found statistically significant (Table:2), except for control to $400 \mathrm{ml}$ sodium arsenite + zeolite $(\mathrm{F}=0.40>5 \% \mathrm{P})$ and $200 \mathrm{ml}$ sodium arsenite + zeolite to $400 \mathrm{ml}$ sodium arsenite + zeolite $(\mathrm{F}=1.17>5 \% \mathrm{P})$. But alterations among duration of treatment were found non-significant (Table: 2).The results revealed that zeolite treatment was effective in decreasing the LDL values significantly to normal range, in comparison to treated ones.

\subsection{Alterations in Triglyceride}

The average control value for Triglyceride from liver was found to be $86.20 \pm 8.81 \mathrm{mg} / \mathrm{dl}$. After exposure to $200 \mathrm{ml}$ of sodium arsenite, it was found decreased up to $25.40 \pm 14.1 \mathrm{mg} / \mathrm{dl}$ for three days; $34.40 \pm 10.31 \mathrm{mg} / \mathrm{dl}$ for 7 days exposure, and for 15 days exposure of the same dose, the concentration of Triglyceride obtained was $72.50 \pm 13.99 \mathrm{mg} / \mathrm{dl}$. At the same time, when exposed to $400 \mathrm{ml}$ of the test solution for three days, the average amount of Triglyceride was again found to be decreased to $56.80 \pm 5.02 \mathrm{mg} / \mathrm{dl}$; for 7 days exposure the average concentration was $60 \pm 5.43 \mathrm{mg} / \mathrm{dl}$ and for 15 days exposure the value was $61.40 \pm 15.11 \mathrm{mg} / \mathrm{dl}$. But when exposed to $200 \mathrm{ml}$ solution of zeolite along with sodium arsenite the average concentration obtained was $48 \pm 6.20 \mathrm{mg} / \mathrm{dl}$ for 3 days, $70.60 \pm 2.97 \mathrm{mg} / \mathrm{dl}$ for 7 days and $53.16 \pm 0.85 \mathrm{mg} / \mathrm{dl}$ for 15 days exposure. Similarly when exposed to $400 \mathrm{ml}$ of sodium arsenite with zeolite, average concentration measured was $67.04 \pm 2.30 \mathrm{mg} / \mathrm{dl}$ for 3 days exposure; $5 \pm 5.43 \mathrm{mg} / \mathrm{dl}$ for 7days exposure; $81.80 \pm 8.23 \mathrm{mg} / \mathrm{dl}$ for 15 days exposure (Fig. 4).

The alteration in Triglyceride from liver extract of Heteropneustes fossilis for dose based treatments with sodium arsenite and sodium, arsenite + zeolite was found statistically significant (Table:2), except for control to $400 \mathrm{ml}$ sodium arsenite + zeolite $(\mathrm{F}=11.6>5 \% \mathrm{P})$ and $400 \mathrm{ml}$ sodium arsenite to $200 \mathrm{ml}$ sodium arsenite + zeolite $(\mathrm{F}=0.52>5 \% \mathrm{P})$. But alterations among duration of treatment were found non-significant (Table: 2).The results revealed that zeolite treatment was effective in bringing back the values to normal, in comparison to treated group (Table:2).The above experiments revealed that pretreatment with higher doses of zeolite can reduce the toxic effect of sodium arsenite can prevent fishes from damage caused by arsenic.

\section{Figures and Tables}

Table 1. showed alteration in Total cholesterol, HDL, LDL \& Triglyceride (mg/dl) from liver extract of Heteropneustes fossilis after acute exposure of Sodium Arsenite (200 \& 400ml/20L of water) and (Sodium Arsenite with Zeolite (200 \& 400ml/20L of water) for 3, 7, and 15 days exposure and compared with control.

\begin{tabular}{|c|c|c|c|c|c|}
\hline Days & Groups & Total Cholesterol $^{1}$ & $\mathrm{HDL}^{1}$ & $\mathrm{LDL}^{1}$ & Triglyceride $^{1}$ \\
\hline & Control & $16.83 \pm 1.19$ & $1.48 \pm 1.05$ & $0.20 \pm 0.03$ & $86.20 \pm 8.81$ \\
\hline 3 days & Arsenic-I dose ${ }^{2}$ & $7.86 \pm 2.09$ & $0.97 \pm 0.35$ & $1.81 \pm 0.36$ & $25.40 \pm 14.1$ \\
\hline
\end{tabular}




\begin{tabular}{llcccc}
\hline \multirow{6}{*}{7 days } & Arsenic-IIdose $^{3}$ & $46.14 \pm 2.27$ & $3.36 \pm 2.24$ & $3.11 \pm 1.08$ & $56.80 \pm 5.02$ \\
& Arsenic+Zeolite-Idose $^{2}$ & $24.10 \pm 1.53$ & $6.70 \pm 0.62$ & $2.10 \pm 0.21$ & $48.00 \pm 6.20$ \\
& Arsenic+Zeolite-IIDose $^{3}$ & $11.73 \pm 4.93$ & $1.70 \pm 0.16$ & $0.80 \pm 0.10$ & $67.04 \pm 2.30$ \\
& Control & $16.83 \pm 1.19$ & $1.48 \pm 1.05$ & $0.20 \pm 0.03$ & $86.20 \pm 8.81$ \\
& Arsenic-I dose $^{2}$ & $15.3 \pm 6.95$ & $4.55 \pm 1.23$ & $3.89 \pm 0.18$ & $34.40 \pm 10.31$ \\
& Arsenic-IIdose $^{3}$ & $40.16 \pm 5.72$ & $6.25 \pm 0.86$ & $6.25 \pm 0.52$ & $60.00 \pm 5.43$ \\
& Arsenic+Zeolite-Idose $^{2}$ & $20.75 \pm 4.99$ & $2.20 \pm 0.45$ & $2.20 \pm 0.70$ & $70.60 \pm 2.97$ \\
& Arsenic+Zeolite-IIDose $^{3}$ & $15.82 \pm 1.06$ & $1.20 \pm 0.05$ & $0.70 \pm 0.08$ & $75.00 \pm 5.43$ \\
& Control $^{15}$ days & $16.83 \pm 1.19$ & $1.48 \pm 1.05$ & $0.20 \pm 0.03$ & $86.20 \pm 8.81$ \\
& Arsenic-I dose $^{2}$ & $44.34 \pm 4.92$ & $3.80 \pm 0.56$ & $4.12 \pm 4.44$ & $72.50 \pm 13.99$ \\
& Arsenic-IIdose $^{3}$ & $48.33 \pm 7.01$ & $11.56 \pm 0.61$ & $11.56 \pm 1.01$ & $61.40 \pm 15.11$ \\
& Arsenic+Zeolite-Idose $^{2}$ & $29.75 \pm 11.11$ & $1.00 \pm 0.17$ & $1.00 \pm 0.06$ & $53.16 \pm 0.85$ \\
& Arsenic+Zeolite-IIDose $^{3}$ & $12.22 \pm 0.86$ & $1.38 \pm 0.20$ & $0.30 \pm 0.03$ & $81.80 \pm 8.23$ \\
\hline
\end{tabular}

${ }^{1}$ Values in $\mathrm{mg} / \mathrm{dl} \pm \mathrm{SD}$

$\begin{array}{lll}\text { Arsenic: } & { }^{2} \text { I Dose: } 200 \mathrm{ml} & { }^{3} \text { II Dose: }-400 \mathrm{ml} \\ \text { Arsenic+Zeolite: } & { }^{2} \text { I Dose: } 200 \mathrm{ml} & { }^{3} \text { II Dose: }-400 \mathrm{ml}\end{array}$

Table 2. Showed level of test of significance (ANOVA) for Sodium arsenite induced alteration in Total cholesterol, HDL, LDL\& Triglyceride (mg/dl) from liver extract of Heteropneustes fossilis and chelating effect of zeolite.

\section{Significant level Among}

Total Cholesterol

\section{ANOVA - F Value}

HDL

LDL

Triglyceride

\section{Alteration among dose}

Control- Arsenic-I dose ${ }^{2}$

Control- Arsenic-IIdose ${ }^{3}$

Control-Arsenic+Zeolite-Idose ${ }^{2}$

Control- Arsenic+Zeolite-IIDose ${ }^{3}$

Arsenic-I dose ${ }^{2}$ - Arsenic-IIdose ${ }^{3}$

Arsenic-I dose $e^{2}$ - Arsenic + Zeolite-Idose ${ }^{2}$

Arsenic-I dose ${ }^{2}-$ Arsenic+Zeolite-IIDose $^{3}$

Arsenic-IIdose ${ }^{3}$ - Arsenic + Zeolite-Idose ${ }^{2}$

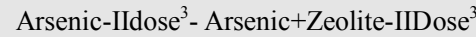

Arsenic+Zeolite-Idose ${ }^{2}-$ Arsenic $+Z e o l i t e-I I D o s e^{3}$

\section{Alteration among duration}

$\begin{aligned} 5.6 & <5 \% \mathrm{P} \\ 25.8 & <5 \% \mathrm{P} \\ 8.04 & <5 \% \mathrm{P} \\ 3.57 & <5 \% \mathrm{P} \\ 22.2 & <5 \% \mathrm{P} \\ 2.37 & >5 \% \mathrm{P} \\ 9.25 & <5 \% \mathrm{P} \\ 19.8 & <5 \% \mathrm{P} \\ 31.4 & <5 \% \mathrm{P} \\ 11.6 & <5 \% \mathrm{P} \\ & \\ 4.5 & >5 \% \mathrm{P} \\ 4.94 & >5 \% \mathrm{P} \\ 13.5 & <5 \% \mathrm{P} \\ 0.44 & >5 \% \mathrm{P} \\ 8.96 & >5 \% \mathrm{P} \\ 8.52 & >5 \% \mathrm{P}\end{aligned}$

Control-3days

Control-7days

Control-15days

3 days- 7 days

3 days- 15 days

7 days-15days

\begin{tabular}{rr}
$8.52>5 \% \mathrm{P}$ & $4.60>5 \% \mathrm{P}$ \\
\hline
\end{tabular}

$1.62>5 \% \mathrm{P}$
$14.9<5 \% \mathrm{P}$
$1.82>5 \% \mathrm{P}$
$0.05>5 \% \mathrm{P}$
$13.3<5 \% \mathrm{P}$
$0.02>5 \% \mathrm{P}$
$1.67>5 \% \mathrm{P}$
$13.1<5 \% \mathrm{P}$
$14.2<5 \% \mathrm{P}$
$1.87>5 \% \mathrm{P}$

$6.96>5 \% \mathrm{P}$
$1.69>5 \% \mathrm{P}$
$2.59>5 \% \mathrm{P}$
$5.27>5 \% \mathrm{P}$
$4.60>5 \% \mathrm{P}$
$0.67>5 \% \mathrm{P}$

$15.74<5 \% \mathrm{P}$

$10.11<5 \% \mathrm{P}$

$1.57<5 \% \mathrm{P}$

$0.40>5 \% \mathrm{P}$

$5.63<5 \% \mathrm{P}$

$14.17<5 \% \mathrm{P}$

$15.34<5 \% \mathrm{P}$

$8.54<5 \% \mathrm{P}$

$9.71<5 \% \mathrm{P}$

$1.17>5 \% \mathrm{P}$

$42.1<5 \% \mathrm{P}$

$26.8<5 \% \mathrm{P}$

$28.3<5 \% \mathrm{P}$

$11.6>5 \% \mathrm{P}$

$15.3<5 \% \mathrm{P}$

$15.8<5 \% \mathrm{P}$

$30.5<5 \% \mathrm{P}$

$0.52>5 \% \mathrm{P}$

$15.21<5 \% \mathrm{P}$

$14.7<5 \% \mathrm{P}$

$3.00>5 \% \mathrm{P} \quad 29.51<5 \% \mathrm{P}$

$2.05>5 \% \mathrm{P}$

$10.4>5 \% \mathrm{P}$

$0.95>5 \% \mathrm{P}$

$7.44>5 \% \mathrm{P}$

$20.96>5 \% \mathrm{P}$

$15.19>5 \% \mathrm{P}$

$8.55>5 \% \mathrm{P}$

$14.56>5 \% \mathrm{P}$

$6.01>5 \% \mathrm{P}$

Arsenic: $\quad{ }^{2}$ I Dose: $200 \mathrm{ml} \quad{ }^{3}$ II Dose: - 400ml

Arsenic+Zeolite: $\quad{ }^{2}$ I Dose: $200 \mathrm{ml} \quad{ }^{3}$ II Dose: - 400ml

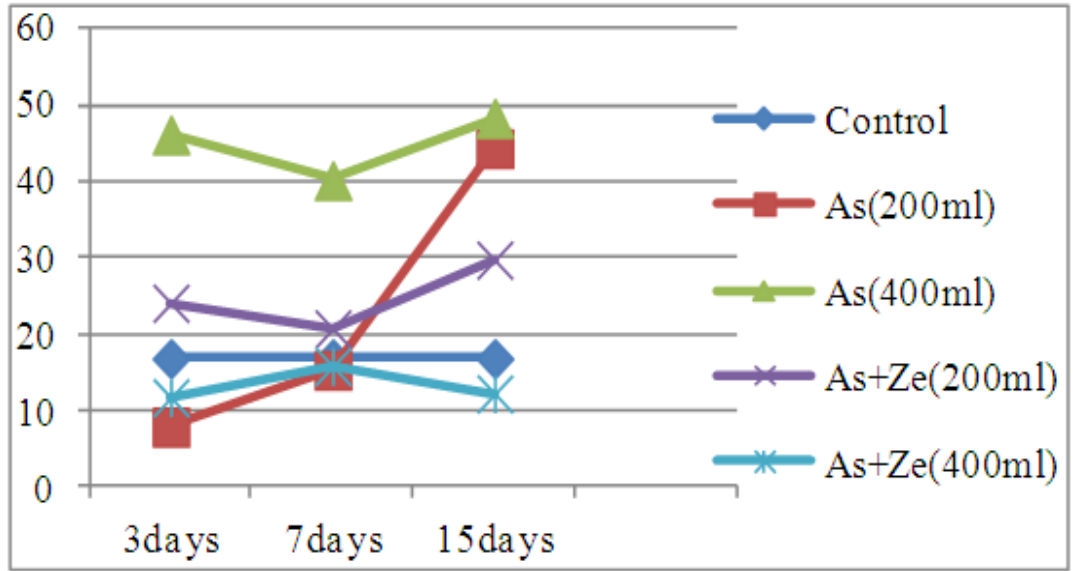

Figure 1. Alteration in Total Cholesterol $(\mathrm{mg} / \mathrm{dl})$ concentration in liver extract of Heteropneustes fossilis after acute exposure of sodium arsenite and sodium arsenite +zeolite 


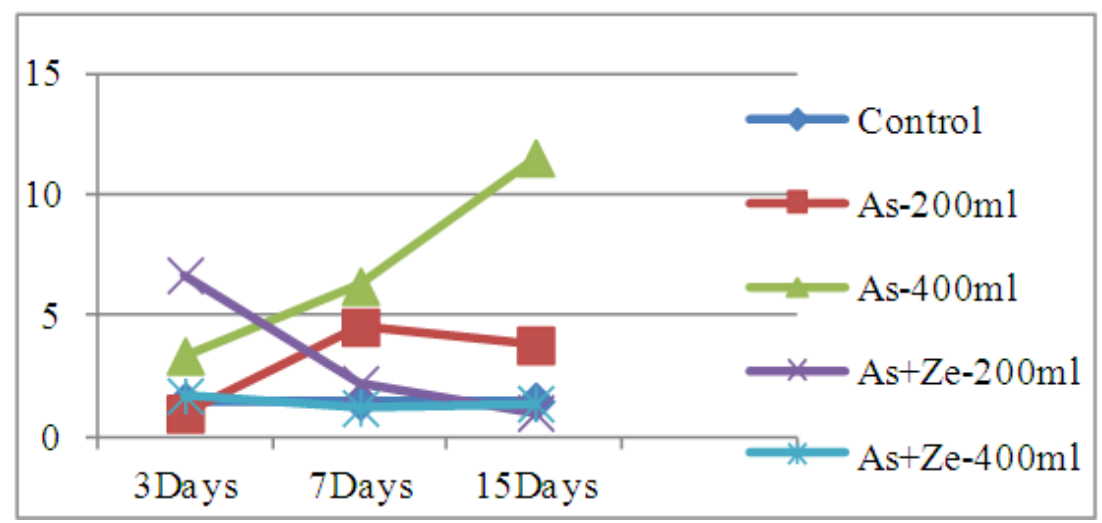

Figure 2. Alteration in HDL Cholesterol( $\mathrm{mg} / \mathrm{dl})$ concentration in liver extract of Heteropneustes fossilis after acute exposure of sodium arsenite and sodium arsenite +zeolite.

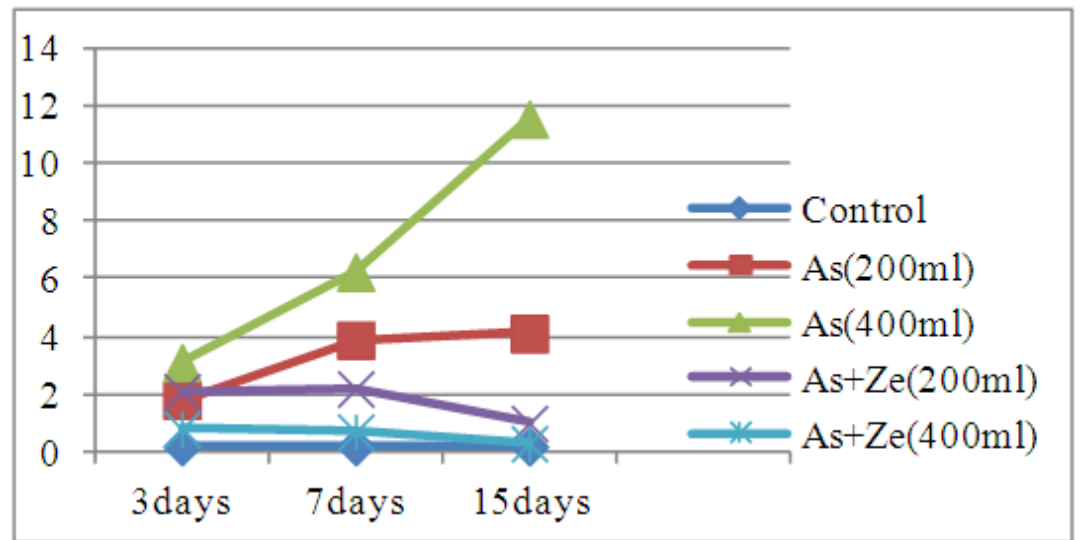

Figure 3. Alteration in LDL cholesterol ( $\mathrm{mg} / \mathrm{dl}$ ) concentration in liver extract of Heteropneustes fossilis after acute exposure of sodium arsenite and sodium arsenite +zeolite.

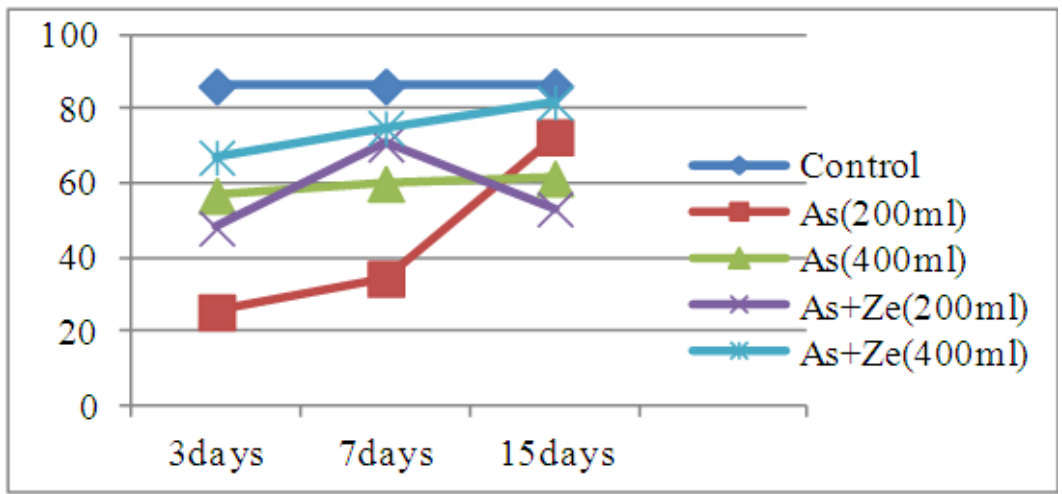

Figure 4. Alteration in Triglyceride ( $\mathrm{mg} / \mathrm{dl}$ ) concentration in liver extract of Heteropneustes fossilis after acute exposure of sodium arsenite and sodium arsenite +zeolite.

\section{Discussion}

The results obtained showed significantly elevated level $(p<0.05)$ of Total cholesterol after exposure to sodium arsenite and significant reduction of the value after exposure to zeolite. The results are in good agreement with the earlier works that reported significant elevation in cholesterol in fresh water fishes exposed to heavy metals.

Jain[10] reported increase in cholesterol content due to lead toxicity in Heteropneustes fossilis and protective role of zeolite by decreasing the toxic effect. Ram and
Satyaneshan[11] reported elevated hepatic cholesterol level which is indicative of liver damage and disruption of its functioning, on exposure of the teleost fish Channa punctatus to mercurial fungicide. Sastry and Sharma[12] recorded an elevation in cholesterol level in the blood of Channa punctatus treated with mercuric chloride and suggested that these changes could be due to hepatic damage and dysfunction. Significant reduction in lipid contents in muscle and gills were reported in Labeo rohita, Cirrhinus mrigala and Catla catla following treatment of sub lethal exposure of heavy metals arsenic and zinc for 45 
days in a study by Garg et al.[13].Our finding is comparable with the findings of the above scientists with regards to the alteration in total cholesterol in liver of Heteropneustes fossilis on exposure to different concentrations of sodium arsenite.

The results also revealed a significantly raised level of HDL cholesterol on exposure to sodium arsenite for all concentrations of doses $(\mathrm{p}<0.05)$ but non-significant increase for duration (Table: 2). But the values decreased significantly to normal after chelation with zeolite.

A significant $(\mathrm{P}<0.05)$ elevation of LDL cholesterol also was reported after exposure to sodium arsenite for all concentrations of doses but non-significant increase for duration (Table: 2).The values showed significant improvement $(\mathrm{P}<0.05)$ to normal after chelation.

The results revealed decrease in concentration of triglycerides below the control value on exposure to sodium arsenite and reversal of the values significantly $(\mathrm{P}<0.05)$ after exposure to zeolite.

\section{Conclusion}

Our findings are comparable with the findings of the previous researchers regarding alteration in Cholesterol, HDL, LDL and Triglyceride content in animals exposed to arsenic and other heavy metals. The findings of the present study indicate that arsenic exposure is responsible for significant alteration in Cholesterol, HDL, LDL and Triglyceride from liver in comparison to control in Heteropneustes fossilis and treatment with zeolite could significantly bring recovery of the conditions in the fish.

The efficacy of zeolites in removing heavy metals, other than arsenic from animal body was evaluated by many workers. But chelating effect of zeolite for arsenic toxicity has not been properly examined. No literature is available for zeolite based chelation of arsenic from any animal body, that is why an attempt was made and significant result was found. We can conclude that like other heavy metals, arsenic load may also be reduced from aquatic fauna by using zeolite. Further structural specification of zeolite and related efficacy of chelation of arsenic is yet to be established.

\section{References}

[1] P.K. Pandey, R.N. Khare, S. Sharma, S.K. Sar, M. Pandey and P. Binayake, Arsenicosis and deteriorating ground water quality: unfolding crisis in central east India region. Curr.Sci.1999, 77:686-693.
[2] USEPA 1996, Clean AIR Act, Section 112 (k): Candidate Pollutants, draft report. Research Triangle Park, North Carolina: United States Environment Protection Agency, Office of Air Quality Planning and Standards, Visibility and Ecosystem Protection Group.

[3] W.H. Lederer and R.J. Fensterheim, Arsenic: Industrial, Biomedical, Environmental Perspectives. 1983, New York: Van Nostrand Reinhold.

[4] K. Hanusch, H. Grossman, K.A. Herbst, B. Rose and H.V. Wolf, Arsenic and Arsenic Compounds. In: Ullmans Encyclopedia of Industrial Chemistry $5^{\text {th }}$ ed. Vol A3. Gerhartz W, Yammamoto Y S , Campbell F T, Pfefferkom R Rounsaville J F eds. Federal Republic of Germany; VCH. 1985, 113-141.

[5] B. Herreros, The X-Ray Diffraction Zeolite Database on the web. Bruno Herreros Homepage.1996.

[6] C.A. Fyfe, G.T. Kakotailo, J.D. Graham, C. Browning, G.C. Gobbi, M. Hyland, G.J. Kennedy and C.T. Deschutter, Demonstration of contact induced ion exchange in zeolites.J.Am.Chem.Soc.1986,Feb1;108(3):522-3.doi:10.10 01/ja00263a036.

[7] S. Shevade, R.G. Ford, Use of synthetic zeolites for arsenate removal from pollutant water: Water Research. 2004; 38:3197-3204.

[8] E. Erdem , N. Karapinar, R. Donat, The removal of heavy metal cations by natural zeolites. J. colloid and Interface Science. 2004; 280: 309-314.

[9] R. James and K. Sampath, Effect of the ion-exchanging agent, zeolite, on reduction of cadmium toxicity: an experimental study on growth and elemental uptake in Heteropneustes fossilis (Bloch). Journal of aquaculture in the tropics.1999, 14: No.1.

[10] S.K. Jain, Protective role of zeolite on short- and long-term lead toxicity in the teleost fish Heteropneustis fossilis. Chemosphere.1999; 39(2): 247-251.

[11] R.N. Ram and A.G. Sathyaneshan, Mercuric chloride induced changes in the protein; lipid and cholesterol levels of the liver and ovary of fish Channa punctatus Environ.Ecol.1984, 2:113-117.

[12] K.V. Sastry and K. Sharma, Effect of mercuric chloride on the activities of the brain enzymes in fresh water teleost Ophiocephalus punctatus. Ecotoxicol.Environ.Saf. 1980, 11: 352-360.

[13] Smitha Garg, R.K.Gupta and K.L.Jain, Sub lethal effects of heavy metals on biochemical composition and their recovery in Indian major carps. Journal of hazardous metals.2009, Vol-163, ssue2-3, 1369-1384. 